\title{
Effect of bio-nutrients with reduced levels of fertilizers, indigenous products and safe insecticides against shoot and fruit borer incidence on brinjal
}

\author{
Jyoti Rekha Mallick, Subhashree Dash* and H. P. Patnaik
}

Department of Entomology, College of Agriculture, Orissa University of Agriculture and Technology, Bhubaneswar (Odisha) India

\section{ARITCLE INFO}

Received : 10.07 .2017

Revised : 18.03 .2018

Accepted : 26.03.2018

\section{KEY WORDS :}

Brinjal, Indigenous products, Bionutrients, Reduced fertilizers, Shoot, Fruit borer, Carbosulfan 25 EC, Spinosad 45SC

*Corresponding author: subhashreedash22@gmail.com

\begin{abstract}
Field studies were undertaken during winter 2012-13 at Bhubaneswar (Odisha) to reveal the impact of indigenous products and bio-nutrients along with reduced levels of fertilizers on the incidence of insect pests of brinjal cv. BLUE STAR. The fruit damage on number (36.4 to $37.2 \%$ ) and weight (39.6 to $40.2 \%$ ) basis varied non- significantly with respect to the nutrient level tested. Six sprays of spinosad $45 \mathrm{SC}$ effectively restricted the fruit damage within 28.0 per cent as against $36.8-42.1$ per cent in untreated control and this was followed by carbosulfan 2119
\end{abstract}

5 EC (32.2 - 34.9\%). The benefit cost ratio was appreciable when the crop was raised with 50\%RDF + Bio-NPK and protected with carbosulfan 25EC(3.44:1) and spinosad 45SC (2.20:1). None of the indigenous products proved effective against shoot and fruit borer incidence.

How to view point the article : Mallick, Jyoti Rekha, Dash, Subhashree and Patnaik, H.P. (2018). Effect of bio-nutrients with reduced levels of fertilizers, indigenous products and safe insecticides against shoot and fruit borer incidence on brinjal. Internat. J. Plant Protec., 11(1) : 109-114, DOI : 10.15740/HAS/IJPP/11.1/109-114. 